\title{
Does the 5-Aminosalicylate Concentration Correlate with the Efficacy of Oral 5-Aminosalicylate and Predict Response in Patients with Inflammatory Bowel Disease? A Systematic Review
}

\author{
Maartje M. van de Meeberg ${ }^{a, b} \quad$ Johannes P.D. Schultheiss ${ }^{a} \quad$ Bas Oldenburg $^{a}$ \\ Herma H. Fidder ${ }^{a}$ Alwin D.R. Huitema ${ }^{b, c}$ \\ aDepartment of Gastroenterology and Hepatology, University Medical Center Utrecht, Utrecht University, Utrecht, \\ The Netherlands; ${ }^{b}$ Department of Clinical Pharmacy, University Medical Center Utrecht, Utrecht University, \\ Utrecht, The Netherlands; ' Department of Pharmacy and Pharmacology, Netherlands Cancer Institute, Amsterdam, \\ The Netherlands
}

\section{Keywords}

Therapeutic drug monitoring · Mesalazine · Ulcerative colitis · Systematic review

\footnotetext{
Abstract

Background: Oral 5-aminosalicylic acid (5-ASA, mesalazine) is the first choice therapeutic agent for treating mild-tomoderate ulcerative colitis (UC). Unfortunately a significant group of patients fail to respond. Therapeutic drug monitoring might help to maintain or induce remission by providing a tool for optimization of 5-ASA therapy. However, plasma and urine concentrations of 5-ASA reflect systemic uptake and are not useful to evaluate therapeutic effect. Objectives: To explore if mucosal and faecal 5-ASA values correlate with disease activity and/or therapeutic effects in patients with inflammatory bowel disease, especially UC. Method: We identified studies that analysed 5-ASA in faeces or mucosa of humans using an oral 5-ASA formulation, using PubMed and
}

Embase. Results: In total, 39 studies ( $n=939)$ were included, 27 on faecal 5-ASA, 9 on mucosal concentrations, and 3 on both faecal and mucosal values. We included 33 cross-sectional studies, 3 randomised clinical trials, 2 longitudinal cohorts and 1 randomized cross-over study. Mucosal 5-ASA concentrations in healthy subjects and patients on equivalent doses of 5-ASA were not found to differ remarkably. In the sub-analysis of mucosal 5-ASA concentrations in patients with active or quiescent UC, a higher concentration was seen during remission. Faecal concentrations were associated with 5-ASA doses but not with disease activity. Differences in faecal or mucosal 5-ASA values could not be ascribed to different 5-ASA formulations. Conclusions: An increase of the mucosal 5-ASA concentrations was observed during remission in patients with UC. No clear relationship between the faecal 5-ASA excretion and the therapeutic efficacy was identified.

(C) 2019 The Author(s) Published by S. Karger AG, Basel

\begin{tabular}{ll}
\hline KARGER & () 2019 The Author(s) \\
& Published by S. Karger AG, Basel Oparger \\
karger@karger.com & This article is licensed under the Creative Commons Attribution- \\
www.karger.com/dig & NonCommercial-NoDerivatives 4.0 International License (CC BY- \\
& NC-ND) (http://www.karger.com/Services/OpenAccessLicense). \\
& Usage and distribution for commercial purposes as well as any dis- \\
tribution of modified material requires written permission.
\end{tabular}




\section{Introduction}

Ulcerative colitis (UC) is a chronic relapsing disease, mainly affecting the large bowel and is characterized by contiguous mucosal inflammation. Literature reports prevalence rates ranging from 90.8 to 505.0 per 100,000 persons in Northern Europe [1]. Oral 5-aminosalicylic acid (5-ASA, mesalazine) is the first choice therapeutic agent for mild to moderate UC due to its effectiveness for both induction (RR 0.86, 95\% CI 0.82-0.89) and maintenance of remission (RR 0.69, 95\% CI 0.62-0.77) [2,3]. In addition to its effectiveness, 5-ASA is a relatively nontoxic and moderately priced drug. Hence, 5-ASA is widely used in UC patients, up to $64 \%$ of Dutch UC patients are treated with 5-ASA [4]. Historically, oral 5-ASA has also been prescribed to patients with Crohn's disease (CD), but its efficacy has not been clearly proven [5].

5-ASA exerts its anti-inflammatory effects locally on the colorectal mucosa. Mechanism of action includes downregulation and inhibition of many inflammatory pathways and enzymes such as cyclooxygenase, lipoxygenases, interleukin-1, tumour necrosis factor- $\alpha$, mitogen activated protein kinase, nuclear factor-kB and p-21 activated kinase-1 [6-9]. Also, induction of peroxisome proliferator-activated receptor $\gamma$ and scavenging of free oxygen radicals have been implicated in the mechanism of action of 5-ASA [10,11].

Local metabolism of 5-ASA consists of acetylation to the inactive metabolite N-Acetyl-5-ASA by the N-acetyltransferase 1 enzyme in intestinal epithelial cells and by intraluminal bacteria. This acetylation process seems to be saturable $[12,13]$. In the liver, $\mathrm{N}$-acetyltransferase 1 metabolises systemically absorbed 5-ASA in a similar manner. 5-ASA is excreted as a mixture of free 5-ASA and $\mathrm{N}$-Acetyl-5-ASA in both urine and faeces [14].

\section{Different Formulations}

A variety of oral 5-ASA formulations are available on the market (online suppl. Table, see www.karger.com/ doi/10.1159/000499331). Since 5-ASA acts topically, all formulations aim to optimise drug delivery to the colonic mucosa with as little systemic absorption as possible [15]. To this end, prodrugs, $\mathrm{pH}$-dependent release and time-dependent release formulations have been developed.

\section{Therapeutic Drug Monitoring}

Although all 5-ASA formulations have been proven to be effective for induction and maintenance of remission in UC, a significant subgroup of patients fails to respond.
Thirty-five per cent of the UC patients fail to reach (partial) remission after 8 weeks induction therapy with 5 -ASA and 52\% fail to maintain complete remission after 12 months maintenance therapy [16]. However, it is presently unclear whether these patients could benefit from a higher 5-ASA dosage $[2,3,17]$. It has been suggested that individual variations in local drug metabolism due to genetic polymorphism, or interactions with the patient's microbiome, explain different responses to 5 -ASA $[18,19]$. The currently available therapeutic options for non-responders include steroids, thiopurines and biologicals, which have more and potentially serious side-effects. In addition, the use of biologicals is associated with higher costs: biologicals are currently the main cost-drivers in the treatment of patients with inflammatory bowel disease (IBD) [4]. Tailoring 5-ASA therapy to the specific needs of patients by therapeutic drug monitoring (TDM) might therefore be a valid alternative strategy, and is already being applied for thiopurines and biologicals.

TDM comprises determination of drug concentrations in the individual patient with subsequent dose adaptation to improve the efficacy and/or safety or to assess drug adherence [20]. Most important before applying TDM, a clear relationship between the drug concentration and (un)wanted clinical effects has to be established [21]. In case of a clear concentration-effect relationship, TDM of oral 5-ASA could be used to evaluate the feasibility of dose intensification, where non-responders with sub-therapeutic concentrations could benefit from tailormade dose finding for treatment optimisation.

Several strategies have been employed to measure the concentration of 5-ASA [22]. The plasma and urine concentration reflect the fraction that is absorbed in the small intestine, which is not available for the topical effect on the colorectal mucosa. Therefore, plasma and urine concentrations can be used to evaluate systemic side effects but not for therapeutic effectiveness [23-25]. On the other hand, the concentration of 5-ASA in the colorectal mucosa or faeces represent local drug bioavailability at the side of action and in the gut lumen, respectively. Therefore, measurement of mucosal or faecal 5-ASA concentration might enable TDM in patients with UC.

A previous systematic review explored the pharmacokinetic profiles of oral 5-ASA formulations including urinary and faecal excretion [26]. In the present systematic review, we aim to explore whether the mucosal and/or faecal 5-ASA concentrations correlate with disease activity and/or therapeutic efficacy in patients with IBD, and thus have potential for TDM in UC patients. 


\section{Materials and Methods}

This systematic review was undertaken in line with the Preferred Reporting Items for Systematic Reviews and Meta-analyses statement [27]. We registered our research protocol at PROSPERO with the following registration number CRD42018084816.

\section{Search Strategy and Study Selection}

We performed a systematic search of PubMed, MEDLINE and Embase databases from inception to January 11, 2018 using keywords relevant to "5-aminosalicylate" and "mucosal concentration" or "faecal concentration" (see Appendix 1 for all search terms). After discarding duplicates, 2 reviewers (M.M.M. and J.P.D.S.) independently screened titles and abstracts for inclusion, followed by full-text screening, using Covidence [28]. Discrepancies were discussed and resolved with a third reviewer (A.D.R.H.). Both reviewers screened reference lists and citations (by Scopus database) of the included studies for additional studies, so called "snowballing".

Inclusion criteria were as follows:

1. Healthy subjects (HS) and IBD (CD and/or UC) patients with an intact colon with the exception of a previous ileocecal resection with anastomosis.

2. Use of a regular oral 5-ASA formulation. "Regular" was defined as no self-designed 5-ASA formulations or uncoated oral 5-ASA. When an oral 5-ASA formulation was combined with topical 5-ASA administration, (part of) the study was not included.

3. Measurement of 5-ASA concentration ( $\mathrm{ng} / \mathrm{mg}$ or $\mathrm{mmol} / \mathrm{L}$ ), recovery of dose (\%) or total amount ( $\mathrm{mg}$ or $\mathrm{mmol}$ ) in intestinal mucosa and/or faeces, faecal water or faecal dialysate. If only the total 5-ASA value (5-ASA plus N-Acetyl 5-ASA) was presented, the study was not included.

We included all (conference) abstracts and original studies, irrespective of design, setting, publication year, publication status restrictions or language.

\section{Data Extraction and Assessment of Bias}

The primary outcome of interest was the measured 5-ASA value. The most important variable was disease activity (if applicable), defined as active colorectal inflammation based on clinical, histologic or endoscopic findings.

The following data was extracted by one reviewer (M.M.M.) and checked by a second reviewer (J.P.D.S): characteristics of study (year, design, main research question), study population (number, UC or HS), disease activity (if applicable), oral 5-ASA formulation (dose, proprietary name), details regarding collection of faeces and mucosal samples (timing, biological material, biopsy site), and 5-ASA concentrations in faeces and/or mucosa. If values were solely presented in figures, Plot Digitizer was used for data extraction. Since oral 5-ASA efficacy has been established in UC patients only, we analysed UC and CD patients if possible separated. We used GraphPad to construct our figures [29].

Two reviewers (M.M.M. and J.P.D.S.) critically appraised all included studies independently and any discrepancies were resolved by discussion with a third reviewer (A.D.R.H.). We developed our own critical appraisal tool because existing tools did not fit the design of the included studies and our research aim (legend detailed in Appendix 2).

TDM of Oral 5-ASA

\section{Results}

\section{Search Results and Study Characteristics}

Figure 1 depicts the search results: 26 of 532 records were eligible. By snowballing we identified another 13 eligible studies [12, 30-41]. The 39 included studies $(n=939)$ included 3 conference abstracts [4244].

In total, 27 studies measured faecal 5-ASA concentrations ( $n=437), 9$ studies mucosal 5-ASA concentrations $(n=445)$ and 3 studies both faecal and mucosal concentrations ( $n=57$; Table 1$) .5$-ASA measurements were carried out in HS in 22 studies $(n=370)$, UC patients in 13 studies $(n=474)$, CD patients in 2 studies $(n=50)$ and both UC and CD patients (IBD) in 4 studies $(n=45)$. The different 5-ASA formulations investigated (number of studies in parenthesis) were: Asacol (19), Pentasa (17), Sulfasalazine (13), Olsalazine (11), Salofalk (3), Apriso (3), Lialda (3), Claversal (2).

\section{Critical Appraisal}

Appendix 2 shows the full critical appraisal. In short, we appraised 8 studies of low (all faecal analysis) and 6 of high relevance. We considered 3 studies of low (all faecal analysis) and 17 studies of high validity. Only one study was appraised with both high relevance and high validity [37].

We observed considerable clinical, methodological and statistical heterogeneity between studies that rendered meta-analysis not possible.

\section{Mucosal Concentration}

\section{Disease and Activity}

Table 2 summarises the mucosal 5-ASA concentrations in HS and patients with UC and CD with active, quiescent or undefined disease activity. Because of the wide variability of 5-ASA concentrations, a clear distinction between HS and disease status could not be made solely based on 5-ASA concentrations.

Strikingly, several individual studies reported lower mucosal 5-ASA concentrations during inflammation. D'Inca et al. [44] found a significant lower mucosal 5-ASA concentration during the active state of UC, both based on endoscopic and histological criteria, compared to quiescent UC (endoscopic active state $35.7 \pm 5.7 \mathrm{ng} / \mathrm{mg}$ vs. remission $60.1 \pm 8.0 \mathrm{ng} / \mathrm{mg}, p=$ 0.02 , and histologic active state $35.5 \pm 5.6 \mathrm{ng} / \mathrm{mg}$ vs. remission $67.5 \pm 9.2 \mathrm{ng} / \mathrm{mg}, p<0.001$ ) [45]. Naganuma et al. [46] detected an inverse correlation between the disease activity index of UC patients and mucosal 
Fig. 1. PRISMA flow diagram depicts our search results and selection of included studies. 5-ASA, 5-aminosalicylic acid.

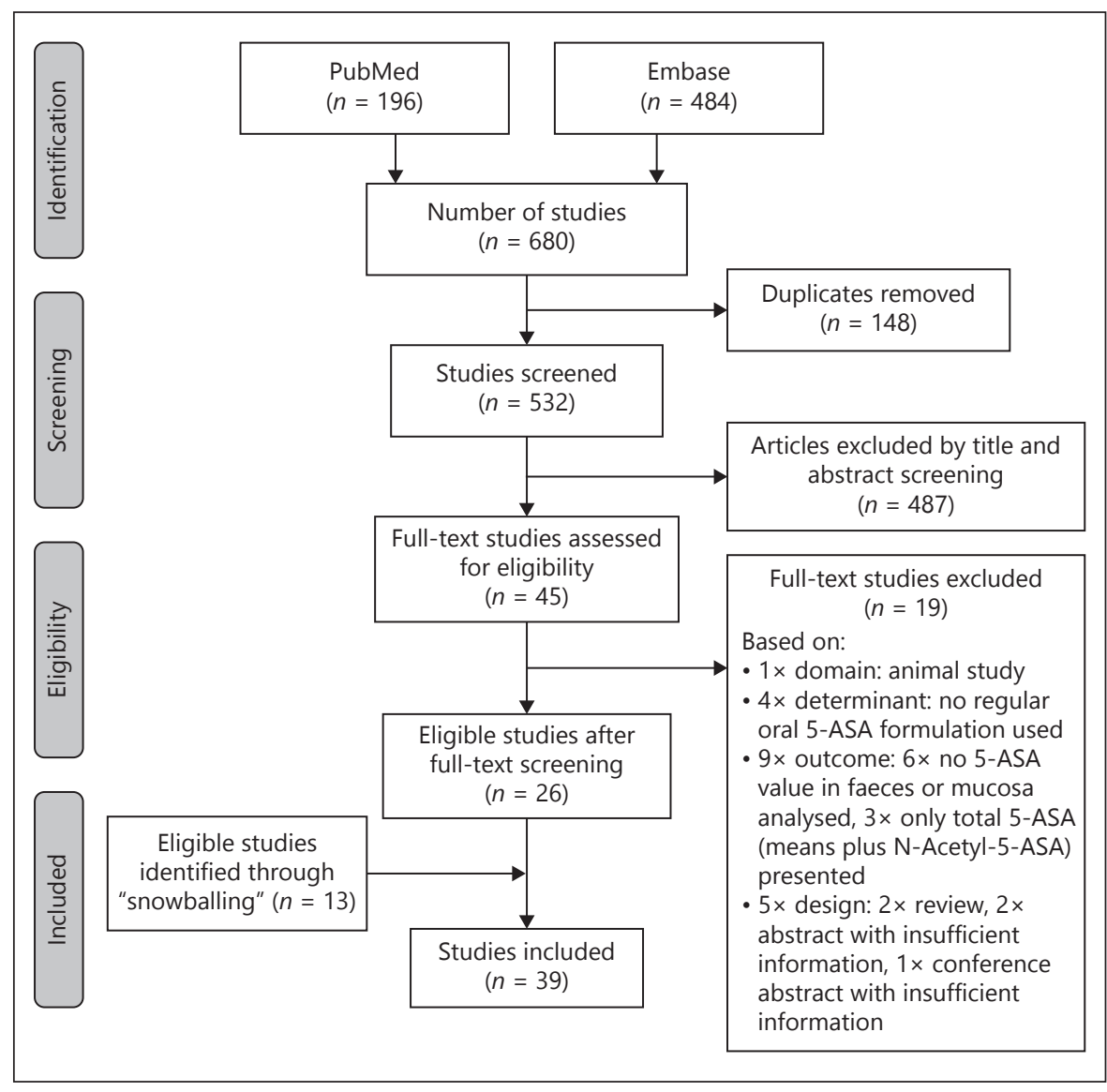

5-ASA concentrations $(r=0.71, p<0.001)$. This finding was confirmed by Frieri et al. [47]. In this study, mucosal 5-ASA cut-off levels were defined for the risk of recurrence in CD patients in whom an ileocecal resection had been performed: $80 \%$ recurrence rate at a colonic mucosal 5-ASA concentration $<20 \mathrm{ng} / \mathrm{mg}, 6 \%$ recurrence rate at a colonic mucosal 5-ASA concentration between 29 and $100 \mathrm{ng} / \mathrm{mg}$ and $0 \%$ recurrence rate at a colonic mucosal 5-ASA concentration higher than $100 \mathrm{ng} / \mathrm{mg}$ [48]. To put this into perspective, $28 \%$ of Asacol users showed a mucosal 5-ASA concentration of $70 \mathrm{ng} / \mathrm{mg}$ or higher [45].

Figure 2 shows a subgroup analysis of 4 studies which scored "+" for domain in our critical appraisal relevance criteria, that is, studies that compared patients with active UC to quiescent UC [44-47]. Patients receiving 2-3 g/day of either Asacol, Pentasa or Sulfasalazine had higher mucosal 5-ASA concentrations during remission in each study. Vice versa, 5-ASA concentrations were found to drop during active disease as compared to quiescent disease in these studies.
Dose and Formulation

Hussain et al. [49] found a significant increase in the mucosal 5-ASA concentrations in HS with increasing doses of Asacol from 1.2 vs. $2.4 \mathrm{~g} /$ day (median $1.6 \mathrm{vs.} 4.2 \mathrm{ng} / \mathrm{mL}$; not shown in Table 2 because of different units) but not significant for 2.4 vs. $4.8 \mathrm{~g} /$ day [13]. However, in our overall analysis, mucosal 5-ASA concentrations did not clearly increase with an increasing dose of 5-ASA therapy (Table 2).

A limited number of studies identified significant different mucosal 5-ASA values when using different formulations. D'Inca et al. [45] found higher mucosal 5-ASA concentrations using Asacol compared to Sulfasalazine and Pentasa and De Vos et al. [50] found lower mucosal 5-ASA concentrations after using azo-bonded prodrugs instead of time- and $\mathrm{pH}$ dependent release mesalazine compounds. Conversely, 2 other studies found higher mucosal concentrations of 5-ASA using the azo bonded pro-drug formula Olsalazine or Sulfasalazine as compared to Pentasa or Salofalk [46, 51]. Altogether, in our systematic analysis, we could not detect a clear difference of mucosal 5-ASA concentrations between the various oral 5-ASA formulations (Table 2). 
Table 1. Characteristics of included studies

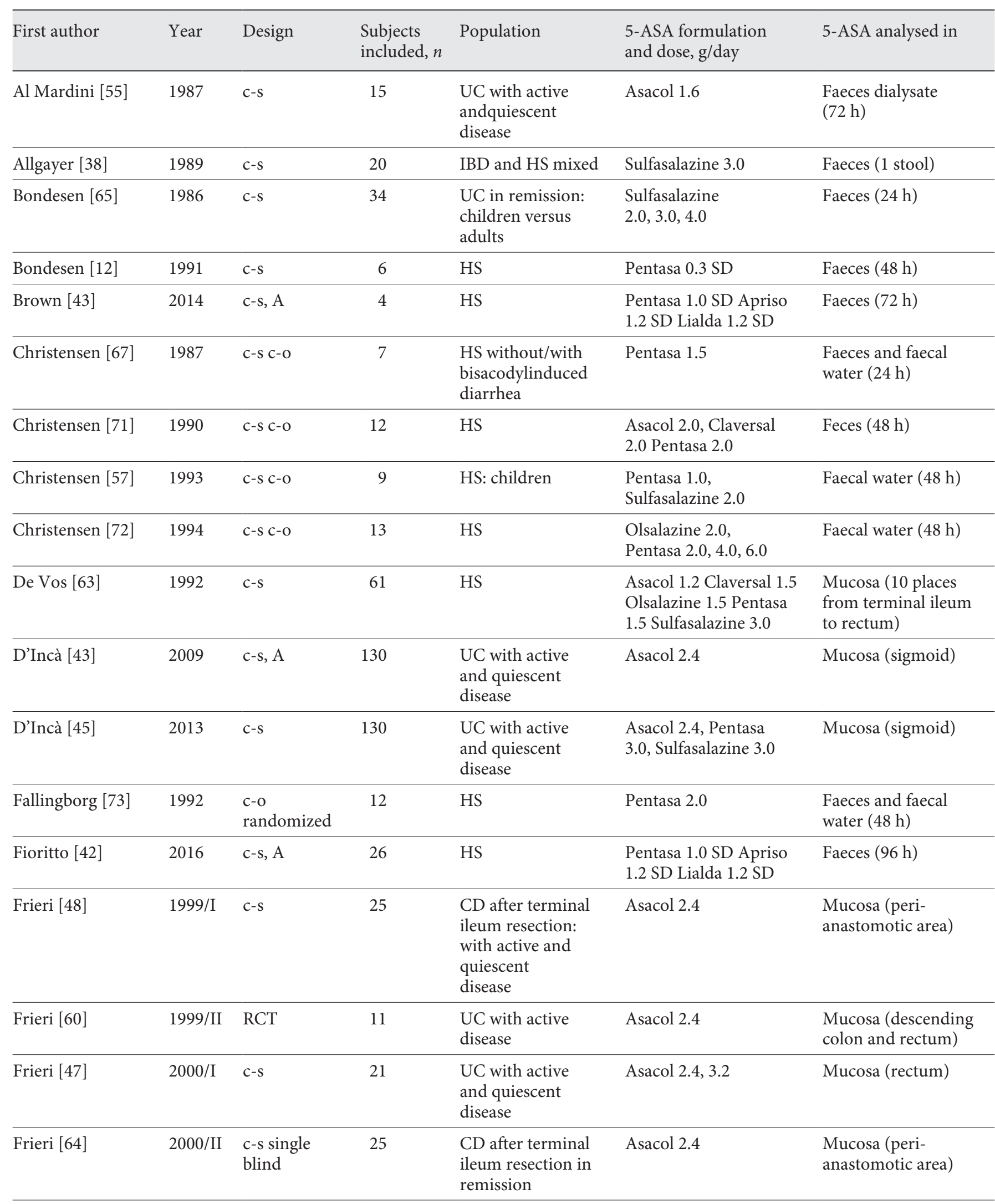


Table 1. (continued)

\begin{tabular}{|c|c|c|c|c|c|c|}
\hline First author & Year & Design & $\begin{array}{l}\text { Subjects } \\
\text { included, } n\end{array}$ & Population & $\begin{array}{l}\text { 5-ASA formulation } \\
\text { and dose, g/day }\end{array}$ & 5-ASA analysed in \\
\hline Frieri [33] & 2005 & longitudinal & 18 & $\mathrm{UC}$ in remission & Asacol 2.4, 3.2 & Mucosa (rectum) \\
\hline Hetzel [40] & 1988 & $\begin{array}{l}\text { RCT with } \\
\text { placebo }\end{array}$ & 30 & $\begin{array}{l}\text { UC with active } \\
\text { disease }\end{array}$ & Olsalazine 1.0 & Faeces (one stool) \\
\hline Hussain [74] & 1998/II & $c-s$ & 34 & HS & Asacol 1.2 & Feces $(24 \mathrm{~h})$ \\
\hline Hussain [13] & 2000 & C-s C-O & 12 & HS & Asacol 1.2, 2.4, 4.8 & $\begin{array}{l}\text { Faeces }(24 \text { h), } \\
\text { mucosa (rectum) }\end{array}$ \\
\hline Hussain [49] & 2001 & $c-s$ & 24 & HS & Asacol 1.2, 2.4, 4.8 & $\begin{array}{l}\text { Faeces }(24 \mathrm{~h}), \\
\text { mucosa (rectum) }\end{array}$ \\
\hline Lauritsen [32] & 1984 & $c-s$ & 18 & HS & $\begin{array}{l}\text { Olsalazine } 0.3,2.0 \\
\text { Sulfasalazine } 2.0\end{array}$ & $\begin{array}{l}\text { Faecal dialysate } \\
(18-72 \mathrm{~h})\end{array}$ \\
\hline Lauritsen [37] & 1988 & longitudinal & 31 & $\begin{array}{l}\text { UC with active } \\
\text { and quiescent } \\
\text { disease }\end{array}$ & $\begin{array}{l}\text { Olsalazine 1.0, 2.0, } \\
3.0,4.0\end{array}$ & $\begin{array}{l}\text { Faecal dialysate } \\
\text { (1 transit time) }\end{array}$ \\
\hline Naganuma [46] & 2001 & c-s & 24 & $\begin{array}{l}\text { UC with active } \\
\text { and quiescent } \\
\text { disease }\end{array}$ & $\begin{array}{l}\text { Pentasa } 2.3 \\
\text { Sulfasalazine } 3.0\end{array}$ & Mucosa (rectum) \\
\hline Peppercorn [30] & 1973 & $c-s$ & 10 & IBD and HS & $\begin{array}{l}\text { Sulfasalazine } 2.0 \\
\text { 3.0, } 4.0 \text { (HS: SD only) }\end{array}$ & Faeces (72 h) \\
\hline Rijk [56] & 1992 & C-S C-O & 20 & $\begin{array}{l}\text { IBD with active } \\
\text { and quiescent } \\
\text { disease }\end{array}$ & $\begin{array}{l}\text { Asacol } 1.2 \\
\text { Olsalazine } 1.5 \\
\text { Pentasa } 1.5 \\
\text { Salofalk } 1.5 \\
\text { Sulfasalazine } 3.0\end{array}$ & Faeces (48 h) \\
\hline Riley [35] & 1991 & C-S C-O & 10 & IBD in remission & Asacol 1.6, 2.4 & Faeces $(24 \mathrm{~h})$ \\
\hline Ryde [41] & 1988 & C-S C-O & 12 & $\begin{array}{l}\text { UC with } \\
\text { unknown disease } \\
\text { activity and HS }\end{array}$ & $\begin{array}{l}\text { Olsalazine } 0.3,3.0 \\
\text { Sulfasalazine } 2.0\end{array}$ & $\begin{array}{l}\text { Faecal dialysate } \\
(24 \mathrm{~h})\end{array}$ \\
\hline $\begin{array}{l}\text { Staerk } \\
\text { Laursen [51] }\end{array}$ & 1990 & C-S C-O & 14 & UC in remission & $\begin{array}{l}\text { Asacol } 2.4 \\
\text { Olsalazine } 1.0,2.0 \\
\text { Pentasa } 2.0 \\
\text { Salofalk } 2.0\end{array}$ & $\begin{array}{l}\text { Faecal dialysate } \\
(24 \mathrm{~h})\end{array}$ \\
\hline $\begin{array}{l}\text { Van Hogezand } \\
{[54]}\end{array}$ & 1985 & C-S C-O & 6 & HS & $\begin{array}{l}\text { Olsalazine } 1.0 \text { SD, } 1.0 \\
\text { Sulfasalazine } 2.3 \text { SD }\end{array}$ & Faeces $(120 \mathrm{~h})$ \\
\hline Willoughby [31] & 1982 & C-S C-O & 8 & HS & $\begin{array}{l}\text { Olsalazine } 0.5 \text { SD, } \\
1.0,2.0\end{array}$ & Faeces (72 h) \\
\hline
\end{tabular}


Table 1. (continued)

\begin{tabular}{|c|c|c|c|c|c|c|}
\hline First author & Year & Design & $\begin{array}{l}\text { Subjects } \\
\text { included, } n\end{array}$ & Population & $\begin{array}{l}\text { 5-ASA formulation } \\
\text { and dose, g/day }\end{array}$ & 5-ASA analysed in \\
\hline $\mathrm{Yu}$ [39] & 1995 & C-S C-O & 20 & HS & Pentasa 1.0 SD & Faeces (96 h) \\
\hline $\mathrm{Yu}[62]$ & 2017 & $c-s$ & 30 & HS & $\begin{array}{l}\text { Pentasa 1.0 SD } \\
\text { Apriso 1.2 SD } \\
\text { Lialda 1.2 SD }\end{array}$ & Faeces (96 h) \\
\hline
\end{tabular}

A, abstract only; c-o, cross-over; c-s, cross-sectional; CD, Crohn disease; HS, healthy subjects; IBD, inflammatory bowel disease (i.e., UC and CD patients mixed); RCT, randomized clinical trial; SD, single dose; UC, ulcerative colitis; 5-ASA, 5-aminosalicylic acid.

Table 2. Mucosal 5-ASA concentrations

\begin{tabular}{|c|c|c|c|c|c|c|c|}
\hline $\begin{array}{l}\text { Daily } \\
\text { dose, } \\
\text { g/day }\end{array}$ & $\begin{array}{l}\text { Proprietary } \\
\text { name }\end{array}$ & Healthy subjects & $\mathrm{UC}$ in remission & $\begin{array}{l}\mathrm{CD} \text { in } \\
\text { remission }\end{array}$ & $\begin{array}{l}\mathrm{UC} \text { in } \\
\text { active state }\end{array}$ & $\begin{array}{l}\mathrm{CD} \text { in } \\
\text { active state }\end{array}$ & $\begin{array}{l}\text { UC with } \\
\text { undefined } \\
\text { activity }\end{array}$ \\
\hline & Olsalazine & $\mathbf{4} \pm \mathbf{3}[49] ; \mathbf{1 1} \pm \mathbf{3}[49]^{\dagger}$ & & & & & \\
\hline $2.0-3.2$ & Asacol & 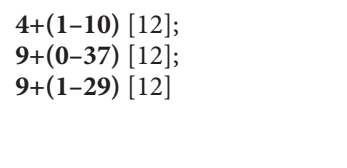 & $\begin{array}{l}3+(1-5)[32] ; \\
2+(10-45)[46] ; \\
17+(11-45)[46] ; \\
60 \pm 8[44] ; \\
68 \pm 9[44]\end{array}$ & $\begin{array}{l}29+(20-81)[62]^{\S} ; \\
60 \pm 33[47] ; \\
71 \pm 47[47]^{\S} ; \\
93+(50-176)[61]^{\S}\end{array}$ & $\begin{array}{l}0+(0-10)[56] ; \\
6+(4-17)[46] ; \\
9+(4-17)[46] ; \\
16+(2-42)[56]^{\ddagger} ; \\
36 \pm 6[44] ; 36 \pm 6[44]\end{array}$ & $\begin{array}{l}22 \pm 28[47]^{\S} \\
26 \pm 26[47]\end{array}$ & $\begin{array}{l}16+(4-45) \\
{[46] ; 52 \pm 6[44]}\end{array}$ \\
\hline 4.8 & Asacol & $\begin{array}{l}\text { 6+(3-9) [12]; 9+(0-19) [12]; } \\
\text { 9+(5-19) [12] }\end{array}$ & N/A & N/A & N/A & N/A & N/A \\
\hline $\begin{array}{r}{ }^{\dagger} \mathrm{Me} \\
{ }^{\ddagger} \mathrm{De} \\
\S \mathrm{Ile} \\
\text { Muc } \\
\text { separate } \\
\mathrm{CD} \text {, }\end{array}$ & $\begin{array}{l}\text { an of } 10 \text { biopsie } \\
\text { cending colon. } \\
\text { Im. } \\
\text { osal } 5 \text {-ASA con } \\
\text { by ‘'?. Studies } \\
\text { Crohn's disease }\end{array}$ & $\begin{array}{l}\text { s taken throughout the entire c } \\
\text { centration in ng/mg is express } \\
\text { with a high validity are bold. Al } \\
\text {; N/A, not applicable; UC, ulcer }\end{array}$ & $\begin{array}{l}\mathrm{d} \text { as mean or medic } \\
\text { biopsies were taken } \\
\text { ative colitis; 5-ASA, }\end{array}$ & $\begin{array}{l}\mathrm{n} \text {, with } \pm \mathrm{SD} / \mathrm{SEM} \text { or } \\
\text { from rectosigmoid } \mathrm{m} \\
5 \text {-aminosalicylic acid }\end{array}$ & $\begin{array}{l}\text { +(range), respectively. } \\
\text { ucosa unless marked. }\end{array}$ & All numbers ar & rounded. Studies are \\
\hline
\end{tabular}

\section{Faecal Analysis}

Disease and Activity

Figure 3 depicts the faecal 5-ASA values as concentration (Fig. 3a), recovery of ingested dose (Fig. 3b) and total amount (Fig. 3c) of all multiple dose studies. The single dose studies (or study parts) analysed only HS and their results were comparable with multiple dose studies [12, $30,31,39,42,43,52-54]$.
Patients with active UC are only represented in Figure 3a: no difference in faecal 5-ASA concentration between HS and patients with active UC was observed. These results were comparable if we only included the multiple dose studies with a high validity. Figure 4 depicts, by linear regression, that the faecal 5-ASA concentration was not different between active and quiescent UC. In contrast, in studies that included patients with IBD, inflammation 


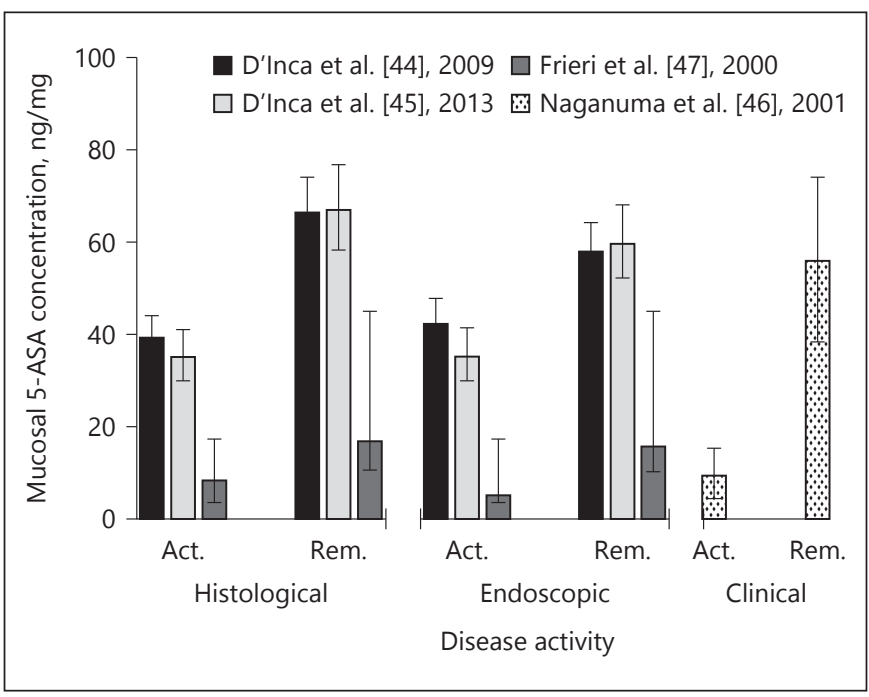

Fig. 2. Mucosal 5-ASA concentrations in ulcerative colitis patients, divided by disease activity. Disease activity, based on histological, endoscopic or clinical findings, is divided into active disease (Act.) or remission (Rem.). Data is expressed as mean \pm SEM, except for Frieri et al. [47] where data is expressed as median + range. All studies have moderate validity concerns. 5-ASA, 5-aminosalicylic acid.

corresponded with lower faecal 5-ASA recovery (Fig. 3b). However, this relationship disappeared when only studies with high validity were included (data not shown).

Four studies compared faecal 5-ASA values in patients with active and quiescent UC or IBD. None found significant differences in faecal 5-ASA excretions based on disease activity $[37,40,55,56]$. Figure 5 displays the results from 2 of these studies that provided quantitative data of faecal 5-ASA $[37,56]$. Lower faecal 5-ASA concentrations during remission were found if patients were on low dose 5-ASA but not when UC patients used higher doses (Fig. 5a). Figure 5b presents contradictory results: the faecal 5-ASA recovery decreases during remission in IBD patients using Asacol, Pentasa and Salofalk but not in patients using Olsalazine and Sulfasalazine.

Dose and Formulation

Hussain et al. [13] found significantly higher faecal 5-ASA amounts by increasing Asacol from 1.2 to $2.4 \mathrm{~g}$ daily but a higher dose of $4.8 \mathrm{~g}$ daily did not significantly further increase faecal excretion. Lauritsen et al. [37] detected higher faecal 5-ASA concentrations for a higher dose of Olsalazine in patients with UC. In our systematic analysis, as shown in Figure 3a, a higher dose of oral 5-ASA correlates with a higher faecal concentration. This dose-concentration effect was even more evident if only high validity studies were included. However, this effect was less pronounced if faecal 5-ASA is expressed as recovery of ingested dose or total amount (Fig. 3b, c).

Conflicting data was reported on faecal 5-ASA values in subjects using different formulations [32, 51, 56-58]. We could not find a clear effect of formulation on faecal 5-ASA excretion (Fig. 3).

\section{Discussion}

In this review, we found a clear inverse relationship between UC disease activity and mucosal 5-ASA concentrations but not with faecal 5-ASA concentrations after oral intake of 5-ASA formulations.

Our finding that an increase in mucosal concentration is associated with quiescent disease is in line with studies that compare oral versus oral plus topical (combination) 5-ASA therapy. Placebo controlled trials showed that combination therapy is more effective than oral therapy alone [59], and pharmacokinetic studies established higher mucosal concentrations during combination therapy than during oral therapy alone $[33,45,46,60,61]$. Frieri et al. [33] analysed both mucosal concentrations and therapeutic efficacy in UC patients using oral therapy versus combination therapy. They conclude that combination therapy leads to higher mucosal concentrations plus less flares, less steroid use, less endoscopies needed and less hospitalisation. These findings strengthen our conclusion that higher mucosal concentrations are associated with less disease activity and thus higher therapeutic efficacy.

We have focused this review on the measurement of 5-ASA concentrations. N-Acetyl-5-ASA has also been measured in several studies, but this is an inactive metabolite. This metabolite has been used to evaluate the release characteristics of the 5-ASA formulation, as it is an indicator of timely (proximal) release of 5-ASA in to the gut lumen, but N-Acetyl 5-ASA is not considered a relevant biomarker for evaluating therapeutic efficacy $[52,56,62]$.

\section{Heterogeneity}

The aforementioned inverse relationship between UC disease activity and mucosal 5-ASA concentrations was conclusive only when studies with a clinical relevant domain were analysed, that is, UC patients with active disease compared to patients in remission in individual studies (Fig. 2). Several factors contributing to the heterogeneity of included studies may explain the absence of a relationship between disease activity and the mucosal 5-ASA concentration when all studies were included in the analysis 


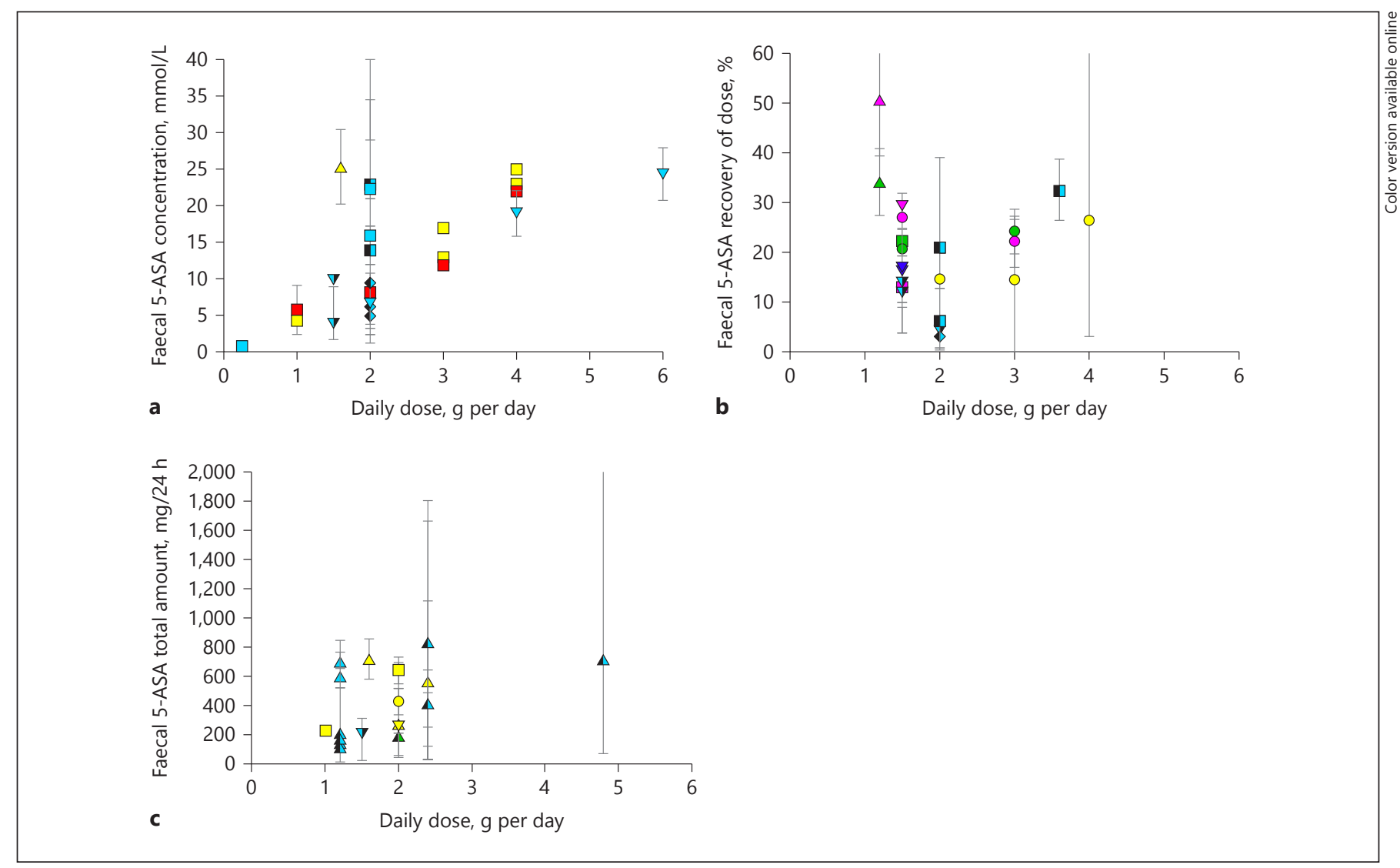

Fig. 3. Values of faecal 5-ASA analysis in multiple dose studies. Faecal 5-ASA is expressed as: (a) concentration $(\mathrm{mmol} / \mathrm{L}),(\mathbf{b})$ recovery of dose (\%), (c) total amount $(\mathrm{mg} / 24 \mathrm{~h})$. Each point in the figure represents one (part of the) study. Shape: $\square$ Olsalazine $\bigcirc$ Sulfasalazine $\triangle$ Asacol $\nabla$ Pentasa $\diamond$ Claversal $\square$ Salofalk. Co-

(Table 2). First and foremost, mucosal 5-ASA concentrations have a high intrasubject variability (intrasubject coefficient of variation: 54\%, range 0-173\%) [34]. Second, the mucosal 5-ASA concentration is significantly lower after mucosal washing before biopsy, but whether mucosal washing was performed was not always specified in the included studies [34]. Third, the site of biopsy may affect the outcome. Although De Vos et al. [63] found no ileum-colon concentration gradient in the steady-state intramucosal concentration for several oral 5-ASA formulations in HS, Frieri et al. [60] showed higher mucosal 5-ASA concentrations at the proximal site of the intestine compared to the distal site in CD patients using Asacol. Hence, we depicted the location of biopsy taking in Table 2. Fourth, although all mucosal 5-ASA concentrations were determined with high-pressure liquid chromatography, differences in preparation and measurements may have hindered comparison of study outcomes. For example, in lour: red = patients with active ulcerative colitis, yellow $=$ patients with ulcerative colitis in remission (or disease activity not specified), violet $=$ patients with active IBD, green $=$ patients with IBD in remission, blue $=$ HS. Filling: $\square$ mean \pm SEM, $\square$ median + range. 5-ASA, 5-aminosalicylic acid.

some studies 5-ASA concentrations were measured directly after biopsy while others stored the biopsies for different durations at $-80^{\circ} \mathrm{C}$. Another essential point relates to the different included phenotypes of IBD. For instance, Frieri et al. [48] included CD patients with terminal ileum resection and ileocolonic anastomosis, as opposed to all other studies in Table 2 [64]. Since in daily clinical practice oral 5-ASA is prescribed to CD patients as well, we did not exclude CD patients. To minimize bias, we analysed data separately for each type of IBD. Finally, the last factor contributing to heterogeneity is that disease activity of UC or CD patients listed in Table 2 was either based on clinical, endoscopic or histological findings. In addition, studies used different criteria for clinical, endoscopic or histological remission.

In line with studies focussing on mucosal 5-ASA concentrations, studies exploring the faecal 5-ASA concentrations show considerable heterogeneity as well, thereby 
Fig. 4. Linear regression with $95 \%$ confidence interval of faecal 5-ASA concentration $(\mathrm{mmol} / \mathrm{L})$ in ulcerative colitis patients with active disease and during remission. Each point in the figure represent one (part of the) study. The included studies are the same as those displayed in Figure $3 a$. 5-ASA, 5-aminosalicylic acid.
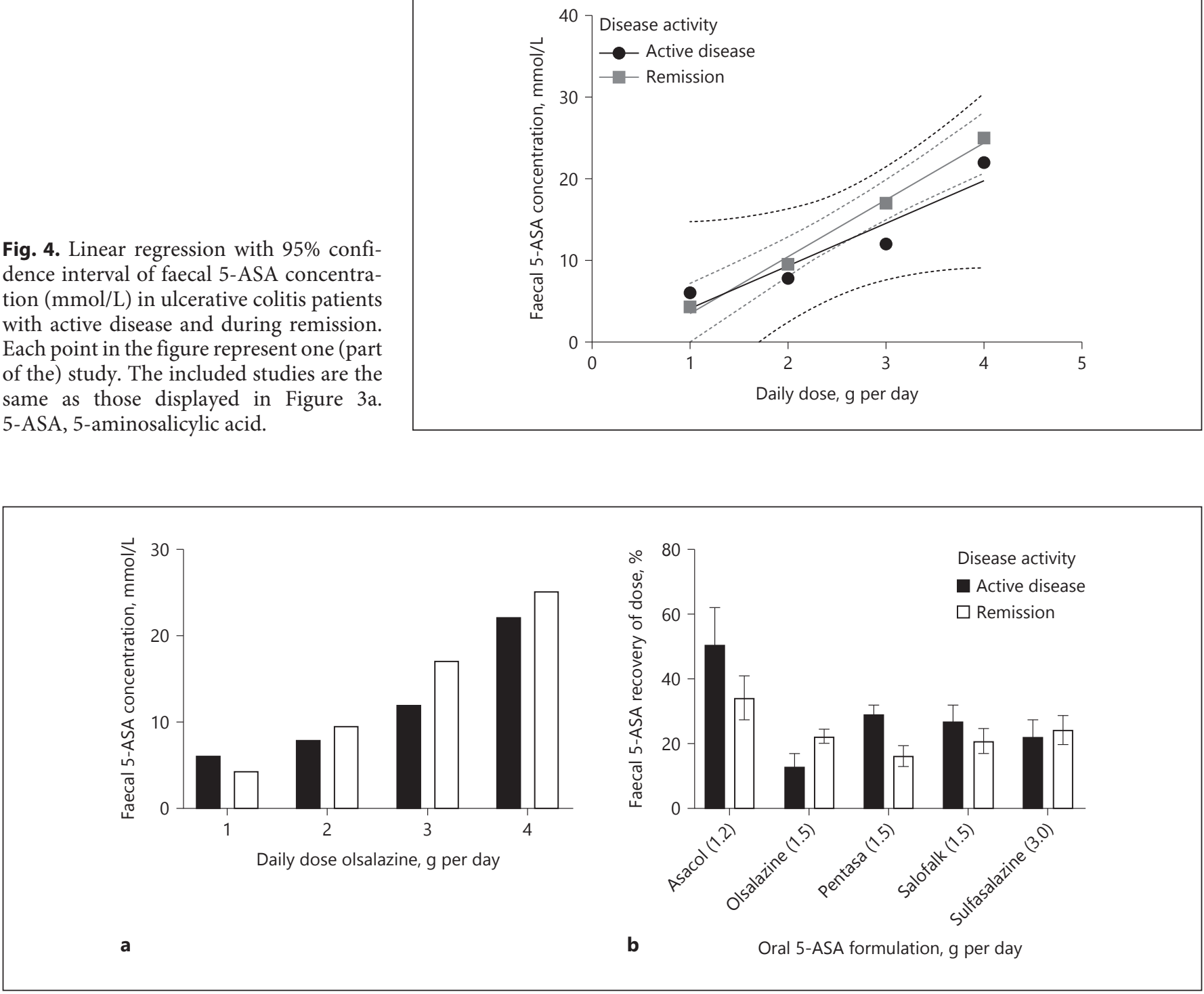

Fig. 5. Faecal 5-ASA excretion divided by disease activity. a Faecal 5-ASA concentration in patients with ulcerative colitis. Data is expressed as mean and derived from Lauritsen et al. [37] (study with high validity). b Faecal 5-ASA as recovery of ingested dose in pa-

precluding to draw definite conclusions on the association of faecal 5-ASA concentrations and disease activity. First, the use of different criteria to score disease activity might have affected the overall results. Second, there were remarkable differences between included subjects. Four studies did not distinguish CD and UC patients but analysed patients as one group ("IBD") [30, 35, 38, 56]. Also, in one study, children were included as well [65]. The recovery of ingested dose was significantly lower in children compared to adults, which may have influenced tients with IBD. Data is expressed as mean \pm SEM and derived from Rijk et al. [56] (study with moderate validity). 5-ASA, 5-aminosalicylic acid.

the overall results of our analysis. Another example is the duration of oral 5-ASA ingestion, which varied between patients or subjects from one single dose (excluded from Fig. 3), to several days or weeks. Third, some studies determined the faecal concentration in a dialysate bag instead of the faeces itself $[32,37,41,51,55]$. Faeces consist of free faecal water plus solid fibrous or bacterial components [32]. Higher concentration of 5-ASA in faeces than in a free faecal water concentration from a dialysate bag can be detected due to the solid fibrous and bacterial 
components that may bind salicylates [40]. Fourth, when interpreting the results of total amount of faecal 5-ASA, it should be taken into account that the collection time of faeces varied per study from 24 to $240 \mathrm{~h}$ (Table 1). To adjust for this variability, the total amount of faecal 5-ASA is expressed per $24 \mathrm{~h}$ (Fig. 3c). Finally, differences in sample pre-treatment, required to prevent degradation of 5-ASA by oxidation and further acetylation by bacterial flora, might have affected the outcomes and hampered thereby a comparison between studies. The stability of faecal compounds is uncertain [66]. Most studies used methanol as storage medium, whereas other studies used methanol plus a phosphate buffer $[13,31,34$, $35,39,49,55,57,67]$ or $\mathrm{HgCl}_{2}[31,36]$. Of note, food intake of subjects has been shown to not influence faecal 5-ASA concentration [53].

\section{Clinical Implications}

Mucosal 5-ASA concentrations may be affected by several patient characteristics during colonic inflammation, such as intestinal transit time. Two studies compared the faecal 5-ASA concentration in HS between normal transit time and accelerated transit time, employing bisacodyl-induced diarrhoea. Both studies reported an increased faecal recovery of the ingested 5-ASA dose during accelerated transit time compared to normal transit time (median 29\%, range $16-38 \%$ vs. $16 \%, 9-21 \%)[52,67]$. In theory, a higher faecal concentration during diarrhoea corresponds to a lower mucosal concentration and thus decreased efficacy, although this relationship has not been clearly established: only 3 studies analysed both faecal and mucosal 5-ASA concentrations, but none of them compared these concentrations in patients with and without diarrhoea/inflammation $[13,34,38,49]$.

In addition to intestinal transit time, intraluminal $\mathrm{pH}$ is often decreased during active inflammation, which may influence the release of 5-ASA from its formulation and thereby influence the mucosal 5-ASA concentration [13, 68]. Further, relevant enzymes and transporters responsible for colonic 5-ASA metabolism and apical secretion back into the colonic lumen may alter during inflammation [14]. On top of that, low mucosal 5-ASA concentrations during active disease might result from a dilution effect secondary to cell oedema. Alternatively, low mucosal 5-ASA concentrations during inflammation may reflect the influence of active lesions, such as ulcers, with increased permeability due to alterations in tight junctions and local leaks, plus a secondary loss of mucosal absorption ability $[46,69]$. Another hypothesis is a faster rate of tissue renewal in the presence of inflammation, establishing a washout effect [45]. In this case, a higher mucosal concentration during remission reflects the decreased epithelial cell turnover compared to the healing phase [70].

If colonic inflammation directly leads to a lower mucosal 5-ASA concentration, this can be considered biomarkers for disease activity rather than a tool for TDM. Preferably, a large longitudinal prospective cohort study should be performed to establish a potential causal relationship and the sequence in which events take place (active inflammation resulting in a decrease in mucosal 5-ASA concentration or vice versa).

\section{Limitations}

The fact that a part of the included studies was pharmacokinetic studies presenting 5-ASA levels, hence not (primarily) designed to relate 5-ASA levels with disease activity and/or therapeutic efficacy, hampers the interpretation of our results.

Furthermore, although we found a relationship between mucosal concentration and disease activity, this does not necessarily imply that measuring 5-ASA levels will lead to optimisation of 5-ASA dosing and thus improve clinical efficacy in UC patients. Our study could be a starting point for further research investigating TDM of 5-ASA, as it is the first systematic review exploring this topic.

\section{Conclusion}

Theoretically, TDM of oral 5-ASA may enable individual dose finding where non-responders with sub-therapeutic concentrations could benefit from dose intensification rather than step up therapy. Optimization of oral 5-ASA therapy would be preferable because it is a relatively safe drug and non-expensive compared to biologicals. However as a first step, a clear concentration-effect relationship has to be established before personalized therapy could be an opportunity. In this systematic review, we found that the mucosal 5-ASA concentration may offer a tool for tailoring therapy in UC patients: an increase in the mucosal concentration is associated with remission. It may be speculated that lower mucosal 5-ASA concentrations during maintenance therapy may predispose patients to relapse. Due to the large heterogeneity of studies, a universal threshold concentration could not be identified. Unfortunately assessment of mucosal concentrations is invasive and not always feasible. The assessment of faecal 5-ASA excretion would be an attractive 
alternative if an excretion-effect relationship could be established clearly. Although there is a relationship between the given oral 5-ASA dose and the faecal concentration, no faecal 5-ASA concentration - therapeutic effect relationship has been established yet. Ideally, both the faecal and mucosal concentration-effect relationship of oral 5-ASA in UC patients with active and quiescent disease activity should be established in a single study.

\section{Acknowledgement}

Not applicable.

\section{Statement of Ethics} close.

The authors declare that they have no ethical conflicts to dis-

\section{Disclosure Statement}

H.H.F.: has served as an advisory board member for Ferring, Takeda, AbbVie, Janssen. B.O.: has served as an advisory board member for Cellgene, MSD, Takeda, Abbvie and Janssen. B.O.: has served as a speaker for Ferring and MSD, and has received an unrestricted grant from Abbvie, Janssen, Ferring, dr. Falk, and Takeda. The other authors (M.M.M., J.P.D.S., and A.D.R.H.) do not have conflicts of interests to declare.

\section{Funding Sources}

Not applicable.

\section{Author Contributions}

All authors contributed to the study concept and design. M.M.M.: performed the search. M.M.M. and J.P.D.S.: screened all titles/abstracts, judged for eligibility and appraised all included studies followed by data extraction. A.D.R.H.: resolved any discrepancies during this process of M.M.M. and J.P.D.S.: Data analysis was performed by M.M.M. All authors contributed to the preparation and review of the manuscript. All authors read and approved of the final version of the manuscript.

\section{Appendix 1}

Search Terms

PubMed

("Mesalamine"[Mesh] OR 5-ASA[Title/Abstract] OR 5-aminosalicylate[Title/Abstract] OR 5 aminosalicylate[Title/
Abstract] OR 5-ASA[Title/Abstract] OR 5 ASA[Title/Abstract] OR delzicol[Title/Abstract] OR mesalazine[Title/Abstract] OR mesalamine[Title/Abstract] OR pentasa[Title/Abstract] OR salofalk[Title/Abstract] OR asacol[Title/Abstract] OR claversal[Title/Abstract] OR mezavant[Title/Abstract] OR apriso[Title/Abstract] OR lialda[Title/Abstract] OR mesasal[Title/ Abstract] OR ipocol[Title/Abstract] OR mesren[Title/Abstract] OR colazal[Title/Abstract] OR colazide[Title/Abstract] OR sulfasalazine[Title/Abstract] OR sulphasalazine[Title/ Abstract] OR olsalazine[Title/Abstract] OR balsalazide[Title/ Abstract] OR salicylazosulfapyridine[Title/Abstract] OR salicylazosulphapyridine[Title/Abstract] OR dipentum[Title/Abstract] OR salazopyrin[Title/Abstract]) AND ("Biological Availability"[Mesh] OR bioavailability[Title/Abstract] OR rectal concentration[Title/Abstract] OR colonic concentration[Title/ Abstract] OR tissue concentration[Title/Abstract] OR mucosal concentration[Title/Abstract] OR rectal concentrations[Title/Abstract] OR colonic concentrations[Title/Abstract] OR tissue concentrations [Title/Abstract] OR mucosal concentrations[Title/ Abstract] OR intraluminal concentration[Title/Abstract] OR faecal excretion[Title/Abstract] OR faecal excretions[Title/Abstract] OR fecal excretion[Title/Abstract] OR fecal excretions[Title/ Abstract] OR faecal concentration[Title/Abstract] OR fecal concentration[Title/Abstract] OR faecal concentrations[Title/Abstract] OR fecal concentrations[Title/ Abstract] OR faecal recovery[Title/Abstract] OR fecal recovery[Title/Abstract] OR faecal water concentration[Title/Abstract] OR fecal water concentration[Title/Abstract] OR faecal water concentrations[Title/Abstract] OR fecal water concentrations[Title/Abstract] OR gastrointestinal release[Title/ Abstract] OR gastrointestinal fluid concentration[Title/Abstract] OR gastrointestinal fluid concentrations[Title/Abstract])

\section{EMBASE \\ ("mesalazine"/exp OR "5-ASA":ab,ti OR} "5-aminosalicylate":ab,ti OR “5 aminosalicylate":ab,ti OR “5-ASA":ab,ti OR "5-ASA":ab,ti OR “delzicol”:ab,ti OR “mesalazine”:ab,ti OR “mesalamine”:ab,ti OR "pentasa”:ab,ti OR "salofalk":ab,ti OR “asacol”:ab,ti OR “claversal”:ab,ti OR “mezavant":ab,ti OR “apriso":ab,ti OR “lialda”:ab,ti OR "mesasal":ab,ti OR “ipocol":ab,ti OR “mesren":ab,ti OR “colazal”:ab,ti OR “colazide”:ab,ti OR "sulfasalazine”:ab,ti OR "sulphasalazine":ab,ti OR "olsalazine":ab,ti OR "balsalazide":ab,ti OR "salicylazosulfapyridine":ab,ti OR "salicylazosulphapyridine": ab,ti OR "dipentum":ab,ti OR "salazopyrin":ab,ti) AND ("bioavailability"/exp OR "bioavailability":ab,ti OR "rectal concentration":ab,ti OR “colonic concentration":ab,ti OR "tissue concentration":ab,ti OR "mucosal concentration":ab,ti OR "rectal concentrations":ab,ti OR “colonic concentrations":ab,ti OR "tissue concentrations":ab,ti OR "mucosal concentrations":ab,ti OR "faecal excretion":ab,ti OR "faecal excretions":ab,ti OR "fecal excretion":ab,ti OR "fecal excretions":ab,ti OR "faecal concentration":ab,ti OR "fecal concentration":ab,ti OR "faecal concentrations":ab,ti OR "fecal concentrations":ab,ti OR "faecal recovery":ab,ti OR "fecal recovery":ab,ti OR "faecal water concentration": ab,ti OR "fecal water concentration":ab,ti OR "faecalwaterconcentrations": ab,tiOR "fecalwaterconcentrations":ab,ti OR "gastrointestinal release":ab,ti OR "gastrointestinal fluid concentration":ab,ti OR "gastrointestinal fluid concentrations":ab,ti). 


\section{Appendix 2}

\section{Critical Appraisal}

\begin{tabular}{|c|c|c|c|c|c|c|c|c|c|c|c|c|c|}
\hline \multirow[t]{2}{*}{ Study } & \multicolumn{4}{|c|}{ Relevance } & \multicolumn{9}{|l|}{ Validity } \\
\hline & domain & determinant & outcome & $\begin{array}{l}\text { relevance } \\
\text { total }\end{array}$ & confounding & $\begin{array}{l}\text { selection } \\
\text { bias }\end{array}$ & $\begin{array}{l}\text { missing } \\
\text { data }\end{array}$ & $\begin{array}{l}\text { 5-ASA } \\
\text { analysis }\end{array}$ & $\begin{array}{l}\text { disease } \\
\text { activity }\end{array}$ & uniformity & compliance & $\begin{array}{l}\text { quality } \\
\text { of statistic }\end{array}$ & $\begin{array}{l}\text { validity } \\
\text { total }\end{array}$ \\
\hline $\begin{array}{l}\text { Mucosal analysis } \\
\text { de Vos et al. } \\
\text { [63], } 1992\end{array}$ & - & + & + & \pm & + & N/A & + & + & N/A & + & + & - & + \\
\hline $\begin{array}{l}\text { D’Incà et al. } \\
\text { [44], 2009(A) }\end{array}$ & + & + & + & + & - & + & $?$ & $?$ & + & + & - & + & \pm \\
\hline $\begin{array}{l}\text { D’Incà et al. } \\
\text { [45], } 2013\end{array}$ & + & + & + & + & - & + & - & + & + & + & - & + & \pm \\
\hline $\begin{array}{l}\text { Frieri et al. } \\
\text { [48], 1999 I }\end{array}$ & $+/-$ & + & + & \pm & + & + & + & + & + & + & - & + & + \\
\hline $\begin{array}{l}\text { Frieri et al. } \\
{[60], 1999 \text { II }}\end{array}$ & $+1-$ & + & + & \pm & - & - & + & + & + & + & + & + & \pm \\
\hline $\begin{array}{l}\text { Frieri et al. } \\
{[47], 2000 \text { I }}\end{array}$ & + & + & + & + & - & - & + & + & + & - & - & + & \pm \\
\hline $\begin{array}{l}\text { Frieri et al. } \\
{[64], 2000 \mathrm{II}}\end{array}$ & $+1-$ & + & + & \pm & - & - & + & + & + & - & + & + & \pm \\
\hline $\begin{array}{l}\text { Frieri et al. } \\
{[33], 2005}\end{array}$ & $+1-$ & + & + & \pm & + & + & + & + & + & - & + & + & + \\
\hline $\begin{array}{l}\text { Naganuma et } \\
\text { al. [46], } 2001\end{array}$ & + & + & + & + & + & - & + & + & + & + & - & + & \pm \\
\hline $\begin{array}{l}\text { Mucosal and faec } \\
\text { Hussain et al. } \\
\text { [34], } 1998 \text { I }\end{array}$ & $\begin{array}{l}\text { analysis } \\
+/-\end{array}$ & + & + & \pm & + & - & + & + & - & + & - & + & \pm \\
\hline $\begin{array}{l}\text { Hussain et al. } \\
{[13], 2000}\end{array}$ & - & + & + & \pm & + & N/A & + & + & N/A & + & - & + & + \\
\hline $\begin{array}{l}\text { Hussain et al. } \\
\text { [49], } 2001\end{array}$ & - & + & + & \pm & + & N/A & + & + & N/A & + & - & + & + \\
\hline $\begin{array}{l}\text { Faecal analysis } \\
\text { Allgayer et al. } \\
\text { [38], } 1989\end{array}$ & - & + & + & \pm & + & N/A & + & + & + & - & - & + & \pm \\
\hline $\begin{array}{l}\text { Al Mardini } \\
\text { et al. [55], } 1987\end{array}$ & + & + & + & + & - & - & - & + & - & + & - & + & - \\
\hline $\begin{array}{l}\text { Bondesen et al. } \\
{[65], 1986}\end{array}$ & - & - & $+1-$ & - & + & N/A & + & - & N/A & + & N/A & + & + \\
\hline $\begin{array}{l}\text { Bondesen et al. } \\
{[12], 1991}\end{array}$ & $+/-$ & + & + & \pm & - & - & $+1-$ & + & - & + & + & + & \pm \\
\hline $\begin{array}{l}\text { Brown et al. } \\
{[43], 2014(\mathrm{~A})}\end{array}$ & - & $+1-$ & - & - & + & N/A & $?$ & $?$ & N/A & + & N/A & - & \pm \\
\hline $\begin{array}{l}\text { Christensen et } \\
\text { al. [68], } 1987\end{array}$ & - & + & + & \pm & + & N/A & + & + & N/A & + & - & - & \pm \\
\hline $\begin{array}{l}\text { Christensen } \\
\text { et al. [71], } 1990\end{array}$ & - & + & + & \pm & + & N/A & + & + & N/A & + & + & - & + \\
\hline $\begin{array}{l}\text { Christensen } \\
\text { et al. [57], } 1993\end{array}$ & - & + & + & \pm & + & N/A & + & + & N/A & + & + & + & + \\
\hline $\begin{array}{l}\text { Christensen } \\
\text { et al. [72], } 1994\end{array}$ & - & + & + & \pm & + & N/A & $+1-$ & + & N/A & + & + & + & + \\
\hline $\begin{array}{l}\text { Fallingborg } \\
\text { et al. [73], } 1992\end{array}$ & - & + & + & \pm & + & N/A & + & + & N/A & + & - & + & + \\
\hline $\begin{array}{l}\text { Fioritto et al. } \\
{[42], 2016(\mathrm{~A})}\end{array}$ & - & $+/-$ & - & - & + & N/A & $?$ & $?$ & N/A & + & N/A & + & \pm \\
\hline $\begin{array}{l}\text { Hetzel et al. } \\
{[40], 1988}\end{array}$ & $+/-$ & + & + & \pm & - & - & $+1-$ & + & + & - & - & + & \pm \\
\hline
\end{tabular}




\begin{tabular}{|c|c|c|c|c|c|c|c|c|c|c|c|c|c|}
\hline \multirow[t]{2}{*}{ Study } & \multicolumn{4}{|c|}{ Relevance } & \multicolumn{9}{|l|}{ Validity } \\
\hline & domain & determinant & outcome & $\begin{array}{l}\text { relevance } \\
\text { total }\end{array}$ & confounding & $\begin{array}{l}\text { selection } \\
\text { bias }\end{array}$ & $\begin{array}{l}\text { missing } \\
\text { data }\end{array}$ & $\begin{array}{l}\text { 5-ASA } \\
\text { analysis }\end{array}$ & $\begin{array}{l}\text { disease } \\
\text { activity }\end{array}$ & uniformity & compliance & $\begin{array}{l}\text { quality } \\
\text { of statistic }\end{array}$ & $\begin{array}{l}\text { validity } \\
\text { total }\end{array}$ \\
\hline $\begin{array}{l}\text { Hussain et al. } \\
\text { [74], } 1998 \text { II }\end{array}$ & - & + & - & - & + & N/A & + & + & N/A & + & - & + & + \\
\hline $\begin{array}{l}\text { Ito et al. [53], } \\
2009\end{array}$ & - & + & $+/-$ & \pm & + & N/A & - & + & N/A & + & - & + & \pm \\
\hline $\begin{array}{l}\text { Lauritsen et al. } \\
{[32], 1984}\end{array}$ & $+1-$ & + & + & \pm & + & - & + & + & $+1-$ & - & - & + & \pm \\
\hline $\begin{array}{l}\text { Lauritsen et al. } \\
{[37], 1988}\end{array}$ & + & + & + & + & + & + & + & + & + & - & + & + & + \\
\hline $\begin{array}{l}\text { Peppercorn } \\
\text { and Goldman } \\
{[30], 1973}\end{array}$ & $+/-$ & + & $+1-$ & \pm & - & - & + & - & - & - & - & + & - \\
\hline $\begin{array}{l}\text { Rasmussen et } \\
\text { al. [75], } 1982\end{array}$ & - & $+/-$ & $+1-$ & - & + & N/A & + & + & N/A & + & - & + & + \\
\hline $\begin{array}{l}\text { Rijk et al. [52], } \\
1989\end{array}$ & - & - & $+/-$ & - & + & N/A & + & + & N/A & - & - & + & \pm \\
\hline $\begin{array}{l}\text { Rijk et al. [56], } \\
1992\end{array}$ & $+1-$ & + & $+1-$ & \pm & - & - & + & + & + & + & - & + & \pm \\
\hline $\begin{array}{l}\text { Riley et al. [35], } \\
1991\end{array}$ & $+1-$ & + & - & \pm & + & - & + & + & - & - & - & + & \pm \\
\hline $\begin{array}{l}\text { Ryde et al. [41], } \\
1998\end{array}$ & $+/-$ & + & + & \pm & + & - & - & - & - & - & - & + & - \\
\hline $\begin{array}{l}\text { Staerk Laursen } \\
\text { et al. [51], } 1990\end{array}$ & $+1-$ & + & $+1-$ & \pm & + & - & + & + & + & + & + & + & + \\
\hline $\begin{array}{l}\text { van Hogezand } \\
\text { et al. [54], } 1985\end{array}$ & - & + & $+1-$ & \pm & + & N/A & + & + & N/A & + & - & + & + \\
\hline $\begin{array}{l}\text { Willoughby et } \\
\text { al. [31], } 1982\end{array}$ & - & + & $+1-$ & \pm & + & N/A & + & + & N/A & + & - & + & + \\
\hline $\begin{array}{l}\text { Yu et al. [39], } \\
1995\end{array}$ & - & - & - & - & + & N/A & $+1-$ & + & N/A & - & N/A & - & \pm \\
\hline $\begin{array}{l}\text { Yu et al. [62], } \\
2017\end{array}$ & - & $+/-$ & $+/-$ & - & + & N/A & $+1-$ & + & N/A & + & N/A & + & + \\
\hline
\end{tabular}

Relevance and validity concerns: $+=$ low relevance/validity concerns, $\pm=$ moderate relevance/validity concerns, $-=$ high relevance/validity concerns. For details see below. (A), abstract only; CD, Crohn disease; IBD, inflammatory bowel disease (i.e., UC and CD patients mixed); N/A, not applicable; UC, ulcerative colitis.

Relevance: Legend for Critical Appraisal

Domain

+ Active vs. non-active UC

+/- IBD patients or CD patients alone or disease activity UC not specified and compared

- Healthy subjects

Determinant

+ Clinical relevant dose $=\geq 1 \mathrm{~g} /$ day for at least 7 days

$+/-\geq 1 \mathrm{~g} /$ day for $<7$ days (include once given)

$-<1 \mathrm{~g} /$ day

Outcome

+ Concentration

+/- Recovery of ingested dose

- Total amount
Total Score Relevance

Per item:

$+=1$ point

$+/-=0.5$ point

$-=0$ points

Total:

+3 points

$\pm 1.5-2.5$ points

$-0-1$ points

Validity

These items are not only an appraisal of validity of the studies but also of quality of reporting.

Risk of Confounding

+ (low risk): no causal study, cross-over design, or demographics presented and comparable 
- (high risk): causal study with no demographics presented or not comparable between the groups, no cross-over design

Risk of Selection Bias

+ (low risk) patients and selection process well described

- (high risk) patients and selection process not well described

N/A healthy subjects

Missing Data

+ No missing data

+/- Missing data, explained by authors

- Unexplained missing data

?(A)

Standardized Measurement Procedures (N-Ac-)5-ASA

Analysis

+ Well described

- Not well described

? (A)

Standardized Measurement Score Disease Activity

+ Criteria remission/no remission described and applicable criteria disease activity well described (e.g., Mayo, Truelove and Witts)

+/- Criteria remission/no remission well described but no disease activity described

- Not well described

N/A healthy subjects

Uniformity Study Protocol Execution

+ Uniform
- Not uniform (e.g., first stool in the morning instead of $24 \mathrm{~h}$ collecting; or different dose oral 5-ASA in study participants)

Measurement of Compliance

+ Compliance measured and described

- Compliance not measured and described

N/A studies with patients using only one day an oral 5-ASA formulation

Quality of Statistics of Most Important Outcome

+ Variability of data well presented: summary data of all individuals in average plus range and/or if applicable statistic test mentioned with $\mathrm{p}$-value and/or 95\% confidence interval

- Only individual data, only average (mean, median) given without range (SD, SEM, range, IQR) and/or if applicable statistic test not mentioned or $p$ value and/or 95\% CI not mentioned

Total Score Validity

Per item:

+ and $\mathrm{N} / \mathrm{A}=1$ point

$+/-=0.5$ point

- and $?=0$ points

Total:

$+7-8$ points

\pm 4-6points

$-0-3$ points

\section{References}

1 Ng SC, Shi HY, Hamidi N, Underwood FE, Tang W, Benchimol EI, et al. Worldwide incidence and prevalence of inflammatory bowel disease in the 21st century: a systematic review of population-based studies. Lancet. 2018 Dec;390(10114):2769-78.

2 Wang Y, Parker CE, Bhanji T, Feagan BG, MacDonald JK. Oral 5-aminosalicylic acid for induction of remission in ulcerative colitis. Cochrane Database Syst Rev. 2016 Apr;4: CD000543.

3 Wang Y, Parker CE, Feagan BG, MacDonald JK. Oral 5-aminosalicylic acid for maintenance of remission in ulcerative colitis. Cochrane Database Syst Rev. 2016 May;(5): CD000544

4 van der Valk ME, Mangen MJ, Leenders M, Dijkstra G, van Bodegraven AA, Fidder HH, et al.; COIN study group and the Dutch Initiative on Crohn and Colitis. Healthcare costs of inflammatory bowel disease have shifted from hospitalisation and surgery towards anti-TNFa therapy: results from the COIN study. Gut. 2014 Jan;63(1):72-9.

5 Lim WC, Wang Y, MacDonald JK, Hanauer S. Aminosalicylates for induction of remission or response in Crohn's disease. Co- chrane Database Syst Rev. 2016 Jul;7(7): CD008870.

6 Stolfi C, Fina D, Caruso R, Caprioli F, Sarra $\mathrm{M}$, Fantini MC, et al. Cyclooxygenase-2-dependent and -independent inhibition of proliferation of colon cancer cells by 5 -aminosalicylic acid. Biochem Pharmacol. 2008 Feb; 75(3):668-76

7 Kaiser GC, Yan F, Polk DB. Mesalamine blocks tumor necrosis factor growth inhibition and nuclear factor kappaB activation in mouse colonocytes. Gastroenterology. 1999 Mar;116(3):602-9.

8 Khare V, Lyakhovich A, Dammann K, Lang M, Borgmann M, Tichy B, et al. Mesalamine modulates intercellular adhesion through inhibition of p-21 activated kinase-1. Biochem Pharmacol. 2013 Jan;85(2):234-44.

9 Mahida YR, Lamming CE, Gallagher A, Hawthorne AB, Hawkey CJ. 5-Aminosalicylic acid is a potent inhibitor of interleukin 1 beta production in organ culture of colonic biopsy specimens from patients with inflammatory bowel disease. Gut. 1991 Jan;32(1):50-4.

10 McKenzie SM, Doe WF, Buffinton GD. 5 -aminosalicylic acid prevents oxidant mediated damage of glyceraldehyde-3-phosphate dehydrogenase in colon epithelial cells. Gut. 1999 Feb;44(2):180-5.

11 Rousseaux C, Lefebvre B, Dubuquoy L, Lefebvre $\mathrm{P}$, Romano $\mathrm{O}$, Auwerx I, et al. Intestinal antiinflammatory effect of 5-aminosalicylic acid is dependent on peroxisome proliferatoractivated receptor- $\gamma$. J Exp Med. 2005 Apr; 201(8):1205-15.

12 Bondesen S, Hegnhøj J, Larsen F, Hansen SH, Hansen CP, Rasmussen SN. Pharmacokinetics of 5-aminosalicylic acid in man following administration of intravenous bolus and per os slow-release formulation. Dig Dis Sci. 1991 Dec;36(12):1735-40.

13 Hussain FN, Ajjan RA, Riley SA. Dose loading with delayed-release mesalazine: a study of tissue drug concentrations and standard pharmacokinetic parameters. Br J Clin Pharmacol. 2000 Apr;49(4):323-30.

14 Zhou SY, Fleisher D, Pao LH, Li C, Winward B, Zimmermann EM. Intestinal metabolism and transport of 5-aminosalicylate. Drug Metab Dispos. 1999 Apr;27(4):479-85.

15 Ye B, van Langenberg DR. Mesalazine preparations for the treatment of ulcerative colitis: are all created equal? World J Gastrointest Pharmacol Ther. 2015 Nov;6(4):137-44. 
16 Rubin DT, Bradette M, Gabalec L, Dobru D, Márquez J, Inglis S, et al.; Ulcerative Colitis Remission Study Group. Ulcerative colitis remission status after induction with mesalazine predicts maintenance outcomes: the MOMENTUM trial. J Crohn's Colitis. 2016 Aug;10(8):925-33.

17 Sandborn WJ, Regula J, Feagan BG, Belousova $\mathrm{E}$, Jojic N, Lukas M, et al. Delayed-release oral mesalamine $4.8 \mathrm{~g} / \mathrm{day}$ ( $800-\mathrm{mg}$ tablet) is effective for patients with moderately active ulcerative colitis. Gastroenterology. 2009 Dec;137(6):1934-43.e1.

18 Perrotta C, Pellegrino P, Moroni E, De Palma C, Cervia D, Danelli P, et al. Five-aminosalicylic Acid: an update for the reappraisal of an old drug. Gastroenterol Res Pract. 2015;2015: 456895.

19 Sartor RB, Wu GD. Roles for Intestinal Bacteria, Viruses, and Fungi in Pathogenesis of Inflammatory Bowel Diseases and Therapeutic Approaches. Gastroenterology. 2017 Feb; 152(2):327-339.e4.

20 Eliasson E, Lindh JD, Malmström RE, Beck O, Dahl ML. Therapeutic drug monitoring for tomorrow. Eur J Clin Pharmacol. 2013 May; 69(S1 Suppl 1):25-32.

21 Ensom MH, Davis GA, Cropp CD, Ensom RJ. Clinical pharmacokinetics in the 21st century. Does the evidence support definitive outcomes? Clin Pharmacokinet. 1998 Apr;34(4): 265-79.

22 Harris MS, Lichtenstein GR. Review article: delivery and efficacy of topical 5-aminosalicylic acid (mesalazine) therapy in the treatment of ulcerative colitis. Aliment Pharmacol Ther. 2011 May;33(9):996-1009.

23 Karamanolis DG, Papatheodoridis GV, Xourgias V. Systemic absorption of 5-aminosalicylic acid in patients with inactive ulcerative colitis treated with olsalazine and mesalazine. Eur J Gastroenterol Hepatol. 1996 Nov;8(11):1083-8.

24 De Vos M. Clinical pharmacokinetics of slow release mesalazine. Clin Pharmacokinet. 2000 Aug;39(2):85-97.

25 Lichtenstein GR, Kamm MA. Review article: 5 -aminosalicylate formulations for the treatment of ulcerative colitis-methods of comparing release rates and delivery of 5-aminosalicylate to the colonic mucosa. Aliment Pharmacol Ther. 2008 Sep;28(6):663-73.

26 Sandborn WJ, Hanauer SB. Systematic review: the pharmacokinetic profiles of oral mesalazine formulations and mesalazine pro-drugs used in the management of ulcerative colitis. Aliment Pharmacol Ther. 2003 Jan;17(1):29-42.

27 Moher D, Liberati A, Tetzlaff J, Altman DG. Preferred reporting items for systematic reviews and meta-analyses: the PRISMA statement. BMJ. 2009 Jul;339(b2535):1-8.

28 Covidence systematic review software, Veritas Health Innovation, Melbourne, Australia [Internet]. Available from: Available at www. covidence.org

29 GraphPad Prism version 7.02 for Windows [Internet]. GraphPad Software, La Jolla Cali- fornia, USA. Available from: Available at www.graphpad.com

30 Peppercorn MA, Goldman P. Distribution studies of salicylazosulfapyridine and its metabolites. Gastroenterology. 1973 Feb;64(2): 240-5.

31 Willoughby CP, Aronson JK, Agback H, Bodin NO, Truelove SC. Distribution and metabolism in healthy volunteers of disodium azodisalicylate, a potential therapeutic agent for ulcerative colitis. Gut. 1982 Dec;23(12): $1081-7$.

32 Lauritsen K, Hansen J, Ryde M, Rask-Madsen J. Colonic azodisalicylate metabolism determined by in vivo dialysis in healthy volunteers and patients with ulcerative colitis. Gastroenterology. 1984 Jun;86(6):1496-500.

33 Frieri G, Pimpo M, Galletti B, Palumbo G, Corrao G, Latella G, et al. Long-term oral plus topical mesalazine in frequently relapsing ulcerative colitis. Dig Liver Dis. 2005 Feb;37(2): 92-6.

34 Hussain FN, Ajjan RA, Moustafa M, Anderson JC, Riley SA. Simple method for the determination of 5-aminosalicylic and $\mathrm{N}$-acetyl-5-aminosalicylic acid in rectal tissue biopsies. J Chromatogr B Biomed Sci Appl. 1998 Sep;716(1-2):257-66.

35 Riley SA, Tavares IA, Bishai PM, Bennett A, Mani V. Mesalazine release from coated tablets: effect of dietary fibre. Br J Clin Pharmacol. 1991 Aug;32(2):248-50.

36 van Hees PA, Tuinte JH, van Rossum JM, van Tongeren JH. Influence of intestinal transit time on azo-reduction of salicylazosulphapyridine (Salazopyrin). Gut. 1979 Apr;20(4): 300-4.

37 Lauritsen K, Staerk Laursen L, Bukhave K, Rask-Madsen J. Longterm olsalazine treatment: pharmacokinetics, tolerance and effects on local eicosanoid formation in ulcerative colitis and Crohn's colitis. Gut. 1988 Jul; 29(7):974-82.

38 Allgayer $\mathrm{H}$, Ahnfelt NO, Kruis W, Klotz U, Frank-Holmberg K, Söderberg HN, et al. Colonic $\mathrm{N}$-acetylation of 5-aminosalicylic acid in inflammatory bowel disease. Gastroenterology. 1989 Jul;97(1):38-41

39 Yu DK, Morrill B, Eichmeier LS, Lanman RC, Lanman MB, Giesing DH, et al. Pharmacokinetics of 5-aminosalicylic acid from controlled-release capsules in man. Eur J Clin Pharmacol. 1995;48(3-4):273-7.

40 Hetzel DJ, Shearman DJ, Labrooy J, Bochner F, Imhoff DM, Gibson GE, et al. Olsalazine in the treatment of active ulcerative colitis: a placebo controlled clinical trial and assessment of drug disposition. Scand J Gastroenterol Suppl. 1988;148(sup148 Supplement 148):61-9.

41 Ryde M, Sandberg-Gertzén H, Järnerot G, Lauritsen K, Rask-Madsen J, Ahnfelt NO. Is 5 -aminosalicylic acid delivered directly to the colon by olsalazine? Scand J Gastroenterol. 1988;23(sup148 Supplement 148):104-6.

42 Fioritto AF, Yu A, Baker J, Collins K, Wen B, Wang Y, et al. Direct comparison of in vivo drug release profiles of three locally-acting drug products of mesalamine in the gastrointestinal tract and correlation with systemic exposure and fecal concentrations in healthy humans [Abstract]. Gastroenterology. 2016; 150(4):S696.

43 Brown SW, Bly MJ, Baker J, May K, Fioritto $\mathrm{AF}$, Hasler WL, et al. A novel method to investigate local concentrations of mesalamine in the gastrointestinal tract of healthy volunteers [Abstract]. Gastroenterology. 2014; 146(5):S-367.

44 D’Incà R, Cardin R, Paccagnella M, Bertomoro P, Caruso A, Caccaro R, et al. Determination of 5-ASA and its derivatives in the colonic mucosa of ulcerative colitis patients: A surrogate marker of oxidative damage? [Abstract]. Gastroenterology. 2009; 136(5):A679.

45 D'Incà R, Paccagnella $\mathrm{M}$, Cardin R, Pathak $\mathrm{S}$, Baldo V, Giron MC, et al. 5-ASA colonic mucosal concentrations resulting from different pharmaceutical formulations in ulcerative colitis. World J Gastroenterol. 2013 Sep; 19(34):5665-70.

46 Naganuma M, Iwao Y, Ogata H, Inoue N, Funakoshi S, Yamamoto S, et al. Measurement of colonic mucosal concentrations of 5-aminosalicylic acid is useful for estimating its therapeutic efficacy in distal ulcerative colitis: comparison of orally administered mesalamine and sulfasalazine. Inflamm Bowel Dis. 2001 Aug;7(3):221-5.

47 Frieri G, Giacomelli R, Pimpo M, Palumbo G, Passacantando A, Pantaleoni G, et al. Mucosal 5-aminosalicylic acid concentration inversely correlates with severity of colonic inflammation in patients with ulcerative colitis. Gut. 2000 Sep;47(3):410-4.

48 Frieri G, Pimpo MT, Andreoli A, Annese V, Comberlato M, Corrao G, et al. Prevention of post-operative recurrence of Crohn's disease requires adequate mucosal concentration of mesalazine. Gruppo Italiano per lo Studio del Colon e del Retto. Aliment Pharmacol Ther. 1999 May;13(5):577-82.

49 Hussain FN, Ajjan RA, Kapur K, Moustafa M, Riley SA. Once versus divided daily dosing with delayed-release mesalazine: a study of tissue drug concentrations and standard pharmacokinetic parameters. Aliment Pharmacol Ther. 2001 Jan;15(1):53-62.

50 De Vos M, Verdievel H, Schoonjans R, Beke $R$, De Weerdt GA, Barbier F. Highperformance liquid chromatographic assay for the determination of 5-aminosalicylic acid and acetyl-5-aminosalicylic acid concentrations in endoscopic intestinal biopsy in humans. J Chromatogr A. 1991 Mar; 564(1):296-302.

51 Staerk Laursen L, Stokholm M, Bukhave K, Rask-Madsen J, Lauritsen K. Disposition of 5 -aminosalicylic acid by olsalazine and three mesalazine preparations in patients with ulcerative colitis: comparison of intraluminal colonic concentrations, serum values, and urinary excretion. Gut. 1990 Nov;31(11): 1271-6. 
52 Rijk MC, van Hogezand RA, van Schaik A, van Tongeren JH. Disposition of 5-aminosalicylic acid from 5 -aminosalicylic acid-delivering drugs during accelerated intestinal transit in healthy volunteers. Scand J Gastroenterol. 1989 Dec;24(10):1179-85.

53 Ito H, Furuta S, Sasaki H, Yoshida T, Takano Y, Hibi T. Pharmacokinetics and safety of single and multiple doses of Asacol tablets in Japanese healthy volunteers. Adv Ther. 2009 Aug;26(8):749-61.

54 van Hogezand RA, van Hees PA, Zwanenburg B, van Rossum JM, van Tongeren JH. Disposition of disodium azodisalicylate in healthy subjects. A possible new drug for inflammatory bowel disease. Gastroenterology. 1985 Mar;88(3):717-22.

55 Mardini HA, Lindsay DC, Deighton CM, Record CO. Effect of polymer coating on faecal recovery of ingested 5-amino salicylic acid in patients with ulcerative colitis. Gut. 1987 Sep; 28(9):1084-9.

56 Rijk MC, van Schaik A, van Tongeren JH. Disposition of mesalazine from mesalazine-delivering drugs in patients with inflammatory bowel disease, with and without diarrhoea. Scand J Gastroenterol. 1992 Oct;27(10):8638.

57 Christensen LA, Fallingborg J, Jacobsen BA, Abildgaard K, Rasmussen HH, Rasmussen $\mathrm{SN}$, et al. Bioavailability of 5-aminosalicyclic acid from slow release 5-aminosalicyclic acid drug and sulfasalazine in normal children. Dig Dis Sci. 1993 Oct;38(10):1831-6.

58 Norlander B, Gotthard R, Ström M. Pharmacokinetics of a 5-aminosalicylic acid entericcoated tablet and suppository dosage form. Aliment Pharmacol Ther. 1989 Aug;3(4): $333-42$.

59 Marteau P, Probert CS, Lindgren S, Gassul M, Tan TG, Dignass A, et al. Combined oral and enema treatment with Pentasa (mesalazine) is superior to oral therapy alone in patients with extensive mild/moderate active ulcerative colitis: a randomised, double blind, placebo controlled study. Gut. 2005 Jul;54(7): $960-5$.
60 Frieri G, Pimpo MT, Palumbo GC, Onori L, Viscido A, Latella G, et al. Rectal and colonic mesalazine concentration in ulcerative colitis: oral vs. oral plus topical treatment. Aliment Pharmacol Ther. 1999 Nov;13(11): 1413-7.

61 Pimpo MT, Galletti B, Palumbo G, Viscido A, Gentile P, Caprilli R, et al. Mesalazine vanishing time from rectal mucosa following its topical administration. J Crohn's Colitis. 2010 Feb;4(1):102-5

62 Yu A, Baker JR, Fioritto AF, Wang Y, Luo R, Li S, et al. Measurement of in vivo Gastrointestinal Release and Dissolution of Three Locally Acting Mesalamine Formulations in Regions of the Human Gastrointestinal Tract. Mol Pharm. 2017 Feb;14(2):345-58.

63 De Vos M, Verdievel H, Schoonjans R, Praet M, Bogaert M, Barbier F. Concentrations of 5-ASA and Ac-5-ASA in human ileocolonic biopsy homogenates after oral 5-ASA preparations. Gut. 1992 Oct;33(10):1338-42.

64 Frieri G, Pimpo MT, Palumbo G, Tonelli F, Annese V, Sturniolo GC, et al. Anastomotic configuration and mucosal 5-aminosalicyclic acid (5-ASA) concentrations in patients with Crohn's disease: a GISC study. Gruppo Italiano per lo Studio del Colon e del Retto. Am J Gastroenterol. 2000;95(6):1486-90.

65 Bondesen S, Nielsen OH, Schou JB, Jensen $\mathrm{PH}$, Lassen LB, Binder V, et al. Steady-state kinetics of 5-aminosalicylic acid and sulfapyridine during sulfasalazine prophylaxis in ulcerative colitis. Scand J Gastroenterol. 1986 Aug;21(6):693-700.

66 van Hogezand RA, van Schaik A, van Hees PA, van Tongeren JH. Stability of disodium azodisalicylate (olsalazine) and metabolites in urine and faeces stored at different temperatures. Eur J Drug Metab Pharmacokinet. 1988 Oct-Dec;13(4):261-5.

67 Christensen LA, Slot O, Sanchez G, Boserup J, Rasmussen SN, Bondesen S, et al. Release of 5-aminosalicylic acid from Pentasa during normal and accelerated intestinal transit time. Br J Clin Pharmacol. 1987 Mar;23(3): 365-9.
68 Nugent SG, Kumar D, Rampton DS, Evans DF. Intestinal luminal $\mathrm{pH}$ in inflammatory bowel disease: possible determinants and implications for therapy with aminosalicylates and other drugs. Gut. 2001 Apr;48(4): 571-7.

69 Gitter AH, Wullstein F, Fromm M, Schulzke JD. Epithelial barrier defects in ulcerative colitis: characterization and quantification by electrophysiological imaging. Gastroenterology. 2001 Dec;121(6):1320-8.

70 Prosberg M, Bendtsen F, Vind I, Petersen AM, Gluud LL. The association between the gut microbiota and the inflammatory bowel disease activity: a systematic review and metaanalysis. Scand J Gastroenterol. 2016 Dec; 51(12):1407-15.

71 Christensen LA, Fallingborg J, Abildgaard K, Jacobsen BA, Sanchez G, Hansen SH, et al. Topical and systemic availability of 5-aminosalicylate: comparisons of three controlled release preparations in man. Aliment Pharmacol Ther. 1990 Oct;4(5):523-33.

72 Christensen LA, Fallingborg J, Jacobsen BA, Abildgaard K, Rasmussen $\mathrm{HH}$, Hansen SH, et al. Comparative bioavailability of 5-aminosalicylic acid from a controlled release preparation and an azo-bond preparation. Aliment Pharmacol Ther. 1994 Jun;8(3):289-94.

73 Fallingborg J, Christensen LA, Jacobsen BA, Ingeman-Nielsen $\mathrm{M}$, Rasmussen $\mathrm{HH}$, Abildgaard K, et al. Concomitant administration of cimetidine and Pentasa ${ }^{\circledR}$. Effect on gastrointestinal $\mathrm{pH}$ and on bioavailability of 5-ASA for Pentasa ${ }^{\circledR}$. Drug Investig. 1992; 4(4):351-5.

74 Hussain FN, Ajjan RA, Moustafa M, Weir NW, Riley SA. Mesalazine release from a $\mathrm{pH}$ dependent formulation: effects of omeprazole and lactulose co-administration. Br J Clin Pharmacol. 1998 Aug;46(2):173-5.

75 Rasmussen SN, Bondesen S, Hvidberg EF Hansen SH, Binder V, Halskov S, et al. 5-aminosalicylic acid in a slow-release preparation: bioavailability, plasma level, and excretion in humans. Gastroenterology. 1982 Nov;83(5): 1062-70. 